\title{
Gambaran Histopatologi Rumen dan Retikulum Sapi Bali Akibat Adanya Benda Asing
}

\author{
Histology Examination on Rumen and reticulum of Bali Cattle's Various contained in \\ Foreign Bodies
}

\author{
Eldarya Envisari Depari ${ }^{1}$, Annas Farhani', \\ I Wayan Batan', I Made Kardena ${ }^{3}$
}

\author{
${ }^{1}$ Pendidikan Profesi Dokter Hewan, \\ ${ }^{2}$ Laboratorium Diagnosis Klinik Hewan, ${ }^{2}$ Laboratorium Manajemen dan Penyakit Sapi Bali, \\ ${ }^{3}$ Laboratorium Patologi Veteriner, Fakultas Kedokteran Hewan, Universitas Udayana \\ Jln. Sudirman, Denpasar, Bali, Indonesia \\ Telp. : 0361-223791; Email : bobbatan@yahoo.com
}

\begin{abstract}
Rumen and reticulum hold an important role in the ruminant's digestive tract. During the meal, Bali cattle accidentally ingest foreign objects because they can't distinguish between foreign body object and feed. Cattles do not really chew food before swallowing. This study aims to determine the existence of a foreign body in the stomach and histopathological overview of Bali cattle rumen and reticulum due to a variety of foreign objects. This study used 10 samples of cattle Bali consisting of nine samples of rumen and reticulum contained foreign objects (plastic, metal, wood and stone) and one normal sample of the rumen and reticulum Bali cattle. Samples were obtained from Slaughter House at Mambal, Abian Semal District, Badung regency, Bali. Based on the results of research conducted on the rumen and reticulum Bali cattle, there are a variety of foreign objects such as plastic, metal, wood and stone. Histopathological changes in the mucosa of the rumen and reticulum form of inflammatory cell infiltration from mild to severe. Conclusions from this research that found a foreign body object in the rumen and reticulum Bali cattle, and foreign body objects cause tissue destruction.
\end{abstract}

Keywords : Bali cattle, rumen, reticulum, foreign bodies.

\begin{abstract}
Abstrak
Rumen dan retikulum memegang peranan penting dalam saluran pencernaan ruminansia., Sapi bali secara tidak sengaja menelan benda asing pada saat makan, karena mereka tidak dapat membedakan antara benda asing dan pakan. Penelitian ini bertujuan untuk mengetahui adanya benda asing dalam lambung dan gambaran histopatologi rumen dan retikulum sapi bali akibat berbagai benda asing. Penelitian ini menggunakan 10 sampel dari sapi bali yang terdiri dari sembilan sampel rumen dan retikulum yang terdapat benda asing (plastik, logam, kayu dan batu) dan satu sampel rumen dan retikulum sapi bali yang normal. Sampel diperoleh dari Rumah Potong Hewan (RPH) Desa Mambal, Kecamatan Abian Semal, Kabupaten Badung, Bali. Berdasarkan hasil penelitian yang dilakukan terhadap rumen dan retikulum sapi bali, terdapat berbagai benda asing berupa plastik, logam, kayu dan batu. Perubahan histopatologi pada mukosa rumen dan retikulum berupa infiltrasi sel radang dari ringan sampai berat. Kesimpulan dari penelitian ini bahwa ditemukan adanya benda asing dalam rumen dan retikulum sapi bali, dan benda asing tersebut mengakibatkan kerusakan jaringan.
\end{abstract}

Kata kunci : Sapi, Bali, rumen, retikulum, benda asing. 


\section{Pendahuluan}

Sapi bali merupakan sapi asli Indonesia yang merupakan hasil domestikasi dari banteng (Bibos banteng), hingga saat ini masih hidup liar di Taman Nasional Bali Barat, Taman Nasional Baluran, dan Taman Nasional Ujung Kulon. Sapi bali memiliki keunggulan dan sifat karakteristik yang berbeda dengan sapi lainnyadan menyebar hampir diseluruh wilayah Indonesia dan juga banyak dipelihara di Malaysia, Filipina dan Australia bagian utara (Batan, 2006; Oka et al., 2012).

Lingkungan sekitar pemeliharaan sapi sangat berpengaruh dalam penyediaan pakan bagi sapi bali. Sapi bali biasanya dipelihara dengan cara dilepaskan di lahan pertanian dan dibiarkan mencari makan sendiri, diikat di bawah pohon atau dikandangkan dengan memberikan pakan berupa hijauan atau rumput (Suwandi, 1997). Namun, seiring dengan berkembangnya pembangunan di Bali menyebabkan semakin berkurangnya lahan hijau yang dapat digunakan untuk penggembalaan sapi, sehingga sapi sering dilepaskan untuk mencari makan sendiri dan berkeliaran di lingkungan yang terdapat banyak sampah.

Sapi yang dilepaskan kemungkinan menelan benda asing karena mereka tidak dapat membedakan bahan plastik, logam, kayu, karet dan batu dalam pakan dan tidak benar-benar mengunyah pakan sebelum menelan (Constable, 2012). Hal ini bisa terjadi pada saat sapi digembalakan di padang rumput yang terdapat sampah. Benda asing akan menyebabkan komplikasi yang berbeda sesuai dengan sifat benda asing dan cara masuk ke dalam organ pencernaan (Sumieka, 2010).

Ruminansia mempunyai lambung ganda, ada sebanyak empat bagian, yaitu rumen, retikulum, omasum, dan abomasum. Rumen dan retikulum memegang peranan penting dalam saluran pencernaan ruminansia. Proses fermentasi pakan terjadi di dalam rumen dan siklus utama motilitas rumen selalu dimulai dengan kontraksi retikulum (Braun dan Jacquat, 2011).

Hewan ruminansia yang secara tidak sengaja menelan benda asing adalah hewan yang kekurangan nutrisi dan manajemen pakannya kurang baik, terutama di negara-negara berkembang yang standar manajeman hewannya tidak baik (Nugusu et al., 2013; Abdelaal dan EL-Maghawry, 2014). Adanya benda asing dalam lambung-lambung ternak sapi telah dilaporkan terjadi di Nigeria, Jordania, dan Sudan (Anwar et al., 2013). Hal ini berdampak secara ekonomi dan dapat menyebabkan penurunan produksi sapi dan juga menyebabkan kematian pada sapi. Di Indonesia belum ada laporan adanya berbagai benda asing dalam rumen dan retikulum sapi bali, begitu pula gambaran histopatologinya. Tujuan penelitian ini adalah mengamati gambaran histopatologi rumen dan retikulum Sapi Bali akibat adanya benda asing.

\section{Materi dan Metode}

Penelitian ini menggunakan 10 sampel rumen dan retikulum sapi bali, terdiri dari atas sembilan sampel yang terdapat berbagai benda asing dan satu sampel yang tidak terdapat benda asing. Sampel diperoleh dari Rumah Potong Hewan Desa Mambal, Kecamatan Abiansemal, Kabupaten Badung. Bali.

Sampel jaringan berupa rumen dan retikulum sapi bali diambil setelah dilakukan pengamatan dan pemeriksaan secara patologi anatomi, setelah sapi di sembelih dan organ pencernaanya dikeluarkan 
dari rongga abdomen. Rumen dan retikulum di buka untuk mengetahui ada tidaknya benda asing di dalam organ tersebut dan dilakukan pengamatan terhadap perubahan yang ditimbulkan akibat benda asing secara patologi anatomi, selanjutnya jaringan yang mengalami perubahan dipotong dengan ukuran 1x1 cm dan disimpan dalam larutan Neutral Buffer Formalin 10\% (NBF) kemudian dilanjutkan dengan pembuatan preparat histopatologi sesuai dengan metode yang dilakukan oleh Muntiha (2001) di Laboratorium Patologi Veteriner, Balai Besar Veteriner Denpasar, Bali. Variabel penelitian ini adalah gambaran histopatologis rumen dan retikulum sapi bali yang terdapat berbagai benda asing. Gambaran histopatologis rumen sapi bali yang terdapat berbagai benda asing diamati dengan mikrokop cahaya. Hasil pengamatan dianalisis secara deskriptif.

\section{Hasil dan Pembahasan}

Hasil penelitian dari sampel rumen dan retikulum yang terdapat berbagai benda asing dikategorikan menurut jenis dari benda asing yang diperoleh. Benda asing ditemukan di dalam rumen dan retikulum sapi bali dan berada di antara makanan. Benda asing yang ditemukan pada setiap sapi berbeda bentuk, ukuran, dan jenisnya, seperti: plastik (tali tambang berukuran sedang, tali tambang berukuran besar, kantong plastik, tutup sikat gigi, dan bungkus makanan berupa aluminium foil), logam (kawat dan baterai), kayu (biji mangga) dan batu (keramik). Dalam penelitian ini benda asing jenis plastik paling banyak ditemukan (Gambar 1). Hal ini senada dengan laporan Tesyafe dan Chanie (2012) mengenai benda asing pada ternak yang dipotong di Jimma Municipal Abattoir, Ethiopia Barat Daya, bahwasanya di dalam rumen paling sering ditemukan benda asing bukan logam seperti kantong plastik, tali, rambut, dan kulit. Plastik adalah benda asing yang paling sering diamati dalam rumen (Igbokwe et al., 2003; Roman dan Hiwot, 2010).
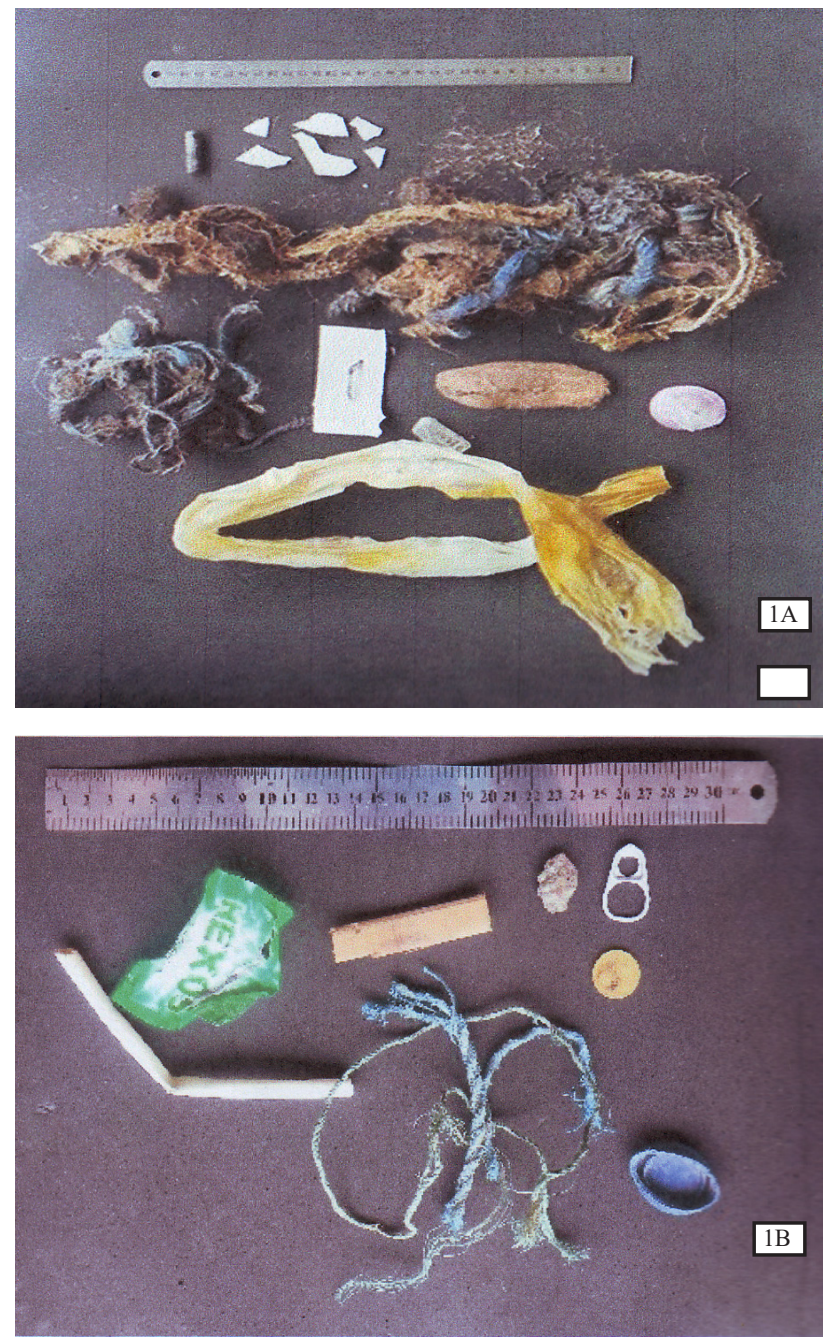

Gambar 1. Benda asing yang ditemukan pada rumen (1A) sapi bali berupa bungkus makanan, kantung plastik, tali tambang plastik, tutup sikat gigi, keramik, biji mangga kering, kawat, dan batu baterai, sedangkan pada reticulum (1B) ditemukan tutup botol air mineral, tali tambang plastic, kabel, kemasan permen, kayu, batu, uang logam dan pembuka minuman kaleng.

Dalam penelitian ini perubahan histopatologi pada retikulum (Gambar 1) ditemukan berupa 
infiltrasi sel-sel radang dan tidak adanya kerusakan yang berarti pada retikulum sapi bali. Benda asing berupa plastik dapat menimbulkan kerusakan berupa hiperplasia hingga ke bawah submukosa dan menunjukkan kerusakan pada jaringan (Bakhiet, 2011). Namun, pada penelitian ini benda asing yang ditemukan hanya menimbulkan infiltrasi sel radang. Gambaran histopatologi retikulum sapi bali yang terdapat berbagai benda asing jenis logam disajikan pada Gambar 2.
Gambaran histopatologi rumen sapi bali (Gambar 3) yang terdapat berbagai benda asing jenis logam seperti kawat teramati terjadi infiltrasi sel radang. Pada rumen yang ditemukan adanya baterai teramati infiltrasi sel radang berat. Benda asing yang tajam pada rumen dapat menyebabkan traumatic pericarditis, traumatic reticuloperitonitis (TRP), abscess reticular, hernia diafragma, gangguan pencernaan, abses hati, abses limpa, pecahnya arteri gastro-epiploika kiri, radang selaput dada, dan abses mediastinum.
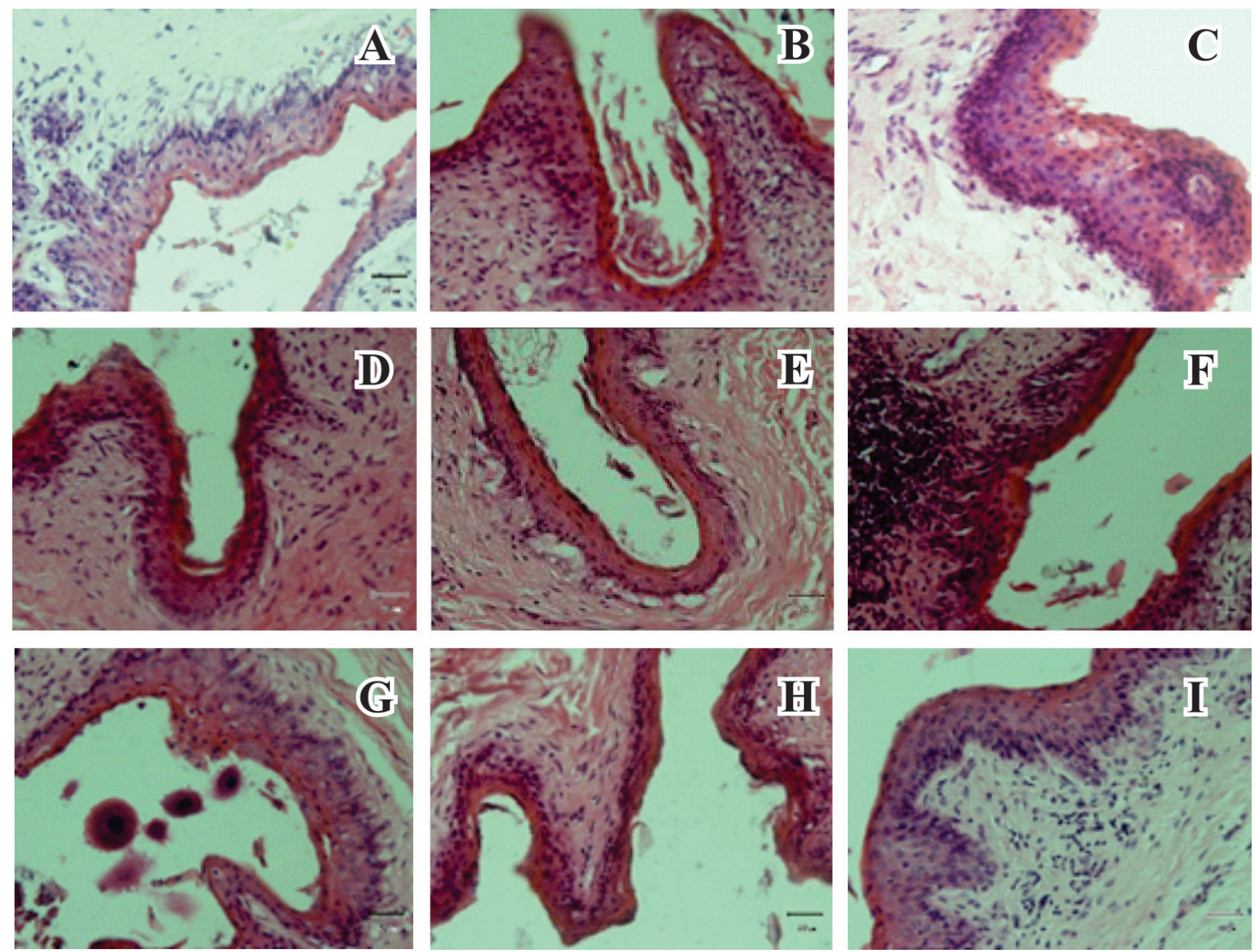

Gambar 2. Gambaran histopatologi retikulum sapi bali yang ditemukan benda asing berupa (A) kabel, adanya infiltrasi sel radang ringan; (B) tutup botol plastic, adanya infiltrasi sel radang ringan; (C) Tali tambang, diamati infiltrasi sel radang sedang; (D) bungkus permen berupa aluminium foil, teramati adanya infiltrasi sel radang yang bersifat ringan; (E) tutup kaleng, diamati adanya infiltrasi sel radang yang bersifat ringan; $(\mathrm{F})$ uang logam, teramati adanya infiltrasi sel radang yang bersifat sedang; $(\mathrm{G})$ batu kecil dan $(\mathrm{H})$ potongan kayu diamati tidak ada perubahan yang disebabkan benda asing; (I) Biji mangga, teramati adanya infiltrasi sel radang yang bersifat ringan. 

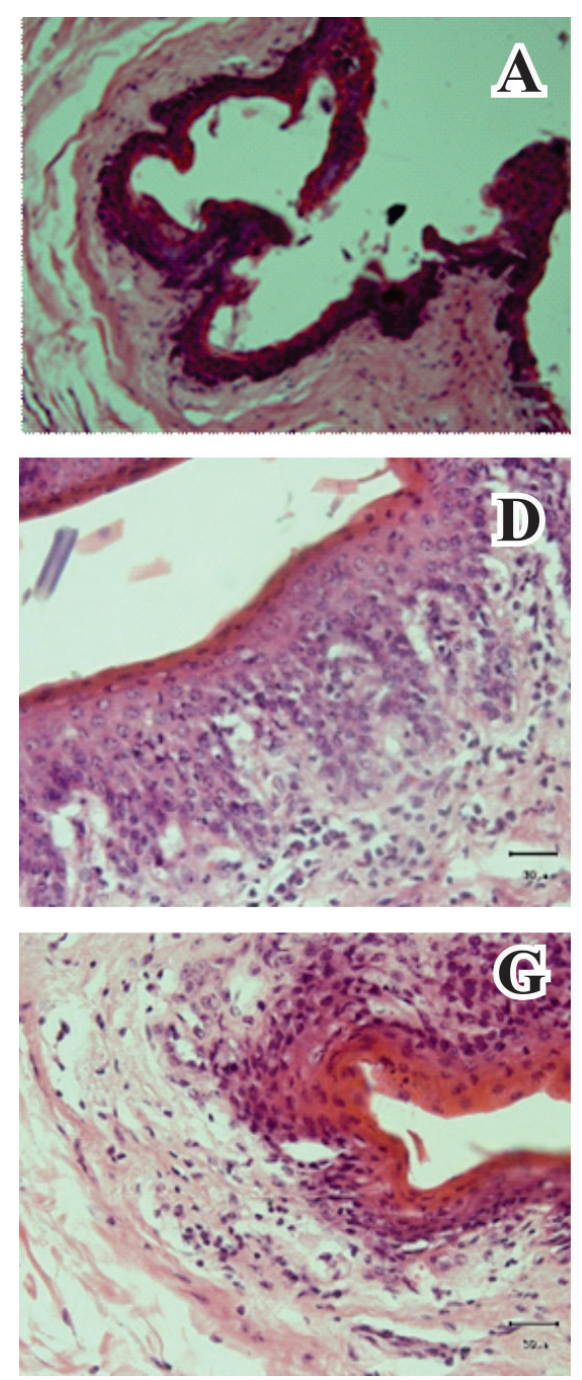
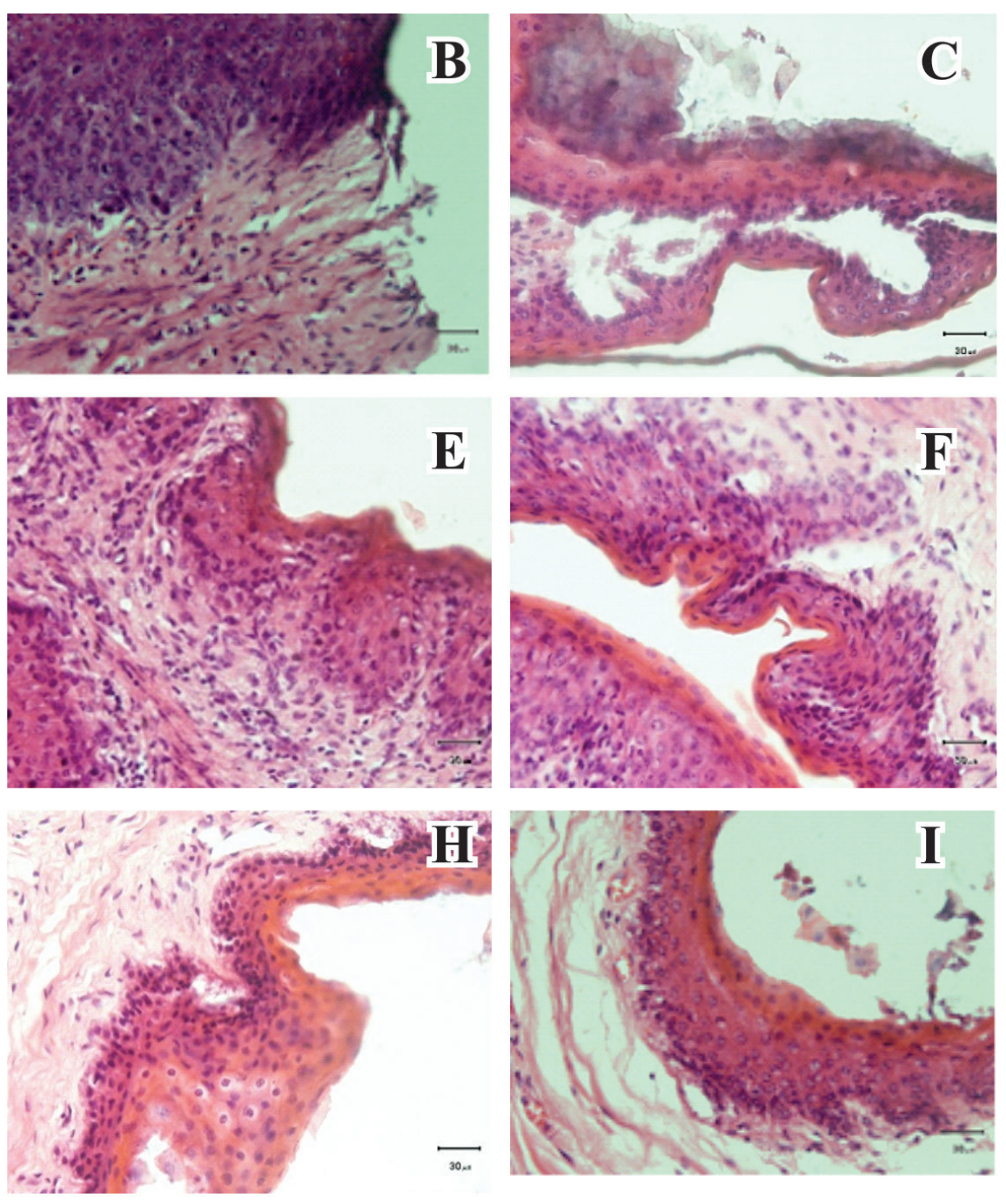

Gambar 3. Gambaran histopatologi rumen sapi bali yang terdapat berbagai benda asing jenis logam seperti (A) Kawat, infiltrasi sel radang sedang; (B) Baterai, infiltrasi sel radang berat; (C) bungkus makanan, infiltrasi sel radang ringan; (D) kantong plastik, infiltrasi sel radang sedang; (E) Tali tambang berukuran besar, Infiltrasi sel radang berat; (F) Tali tambang berukuran sedang, Infiltrasi sel radang berat; dan (G) Tutup sikat gigi, Infiltrasi sel radang sedang; (H) kayu, infiltrasi sel radang ringan. dan (I) Keramik, infiltrasi sel radang ringan.

Pada penelitian ini benda asing yang ditemukan berupa baterai dan kawat kecil yang berlekuk dan tidak tajam, sehingga hal tersebut tidak menimbulkan gangguan seperti pernyataan sebelumnya (Al-abbadi et al., 2014).

Menurut Omid dan Mozaffari (2014), struktur mukosa retikulum yang mirip sarang lebah membuat benda asing dapat berdiam di dalam retikulum, dan kontraksi retikulum yang kuat akan mendorong benda asing tajam menembus dinding retikulum dan menyebabkan traumatic reticuloperitonitis. Benda asing di dalam rumen dapat menyebabkan peluruhan dan pengerdilan papilla rumen, respons inflamasi dan hyperplasia muncul karena adanya tekanan pada dinding rumen yang diakibatkan oleh benda asing (Vanita et al., 2010).

Infiltrasi sel radang yang ditemukan pada retikulum diduga karena respons jaringan pada retikulum terhadap benda asing yang berada di dalam retikulum tersebut, ukuran benda asing juga 
berpengaruh terhadap tingkat kerusakan yang ditimbulkan. Kemungkinan pula benda asing yang ditemukan saat penelitian ini belum terlalu lama berada di dalam retikulum sehingga belum cukup waktu untuk benda asing tersebut menimbulkan kerusakan pada retikulum. Saat dilakukan pembedahan, posisi benda asing tersebut berada ditengah-tegah ingesta rumen atau retikulum, hal tersebut juga dapat memengaruhi tingkat kerusakan pada rumen dan retikulum, karena benda asing tidak selalu bersentuhan langsung dengan permukaan mukosa. Jumlah dan lamanya benda asing berada dalam rumen dan retikulum juga dapat memengaruhi tingkat kerusakan (Nugusu et al., 2013). Benda asing yang mempunyai ukuran relatif besar, seperti plastik dan benda asing lain yang tersangkut di retikulum dan rumen dalam waktu tertentu dapat menyebabkan impaksi dan kematian hewan (Khan et al., 1999).

Berdasarkan hasil penelitian yang dilakukan terhadap rumen dan retikulum sapi bali, ditemukan berbagai benda asing berupa plastik, logam, kayu dan batu. Perubahan histopatologi pada mukosa rumen dan retikulum berupa infiltrasi sel radang dari ringan sampai berat. ukuran benda asing juga berpengaruh terhadap tingkat kerusakan yang ditimbulkan. Kesimpulan dari penelitian ini adalah benda asing ditemukan pada rumen dan retikulum sapi bali dan benda asing tersebut menimbulkan kerusakan jaringan mukosa rumen dan retikulum.

\section{Kesimpulan}

Dari penelitian ini dapat disimpulkan bahwa ditemukan adanya benda asing dalam rumen dan retikulum sapi bali, dan benda asing tersebut mengakibatkan kerusakan jaringan.

\section{Ucapan Terima Kasih}

Ucapan terima kasih penulis ucapkan kepada drh. IKetutEli Supartika, M.Sc dan staff Laboratorium Patologi, Balai Besar Veteriner Denpasar dalam pembuatan preparat histopatologi, serta seluruh pegawai Rumah Potong Hewan Mambal yang telah membantu dalam pengambilan sampel.

\section{Daftar Pustaka}

Abdelaal,A. M., and EL-Maghawry, S(2014) Selected Studies on Foreign Body Impaction in Goats with Special Reference to Ultrasonography. Vet World. 7(7): 522-527.

Abebe, F., and Nuru, M (2011) Prevalence of Indigestable Foreign Body Ingestion in Small Ruminants Slaughtered at Luna Export Abattoir, East Shoa, Ethiopia. J.Anim.Vet. Adv 10(12): 1598-1602.

Al-abbadi, os., abu-seida, am., and al-hussainy, sm (2014)Studies on Rumen Magnet Usage to Prevent Hardware Disease in Buffaloes. Vet World. 7 (6) : 408-411.

Anwar, K., Khan, I.,Aslam,A., Mutjaba, M., Din,A.,Amin, Y., and Ali, Z (2013) Prevalence Of Indigestible Rumen And Retikulum Foreign Bodies In Achai Cattleat Different Regions Ofkhyber Pakhtunkhwa. ARPN Journal of Agricultural and Biological Science. 8(8): 580-586.

Bakhiet, O.A(2008) Studies on The Rumen Pathology of Sudanese Desert Sheep in Slaughter House Scientific Research and Essay 3(7): 294-298.

Batan, I.W (2006) Sapi bali dan penyakitnya. Denpasar; Fakultas Kedoketran Hewan Universitas Udayana.

Braun U, Jacquat, D (2011) Ultrasonography of the retikulum in 30 healthy Saanen goats. Acta Veterinaria Scandinavica 53:19. doi: 10.1186/1751-0147-53-19.

Ghanem, M. M (2010) A Comparitive Study on Traumatic Reticuloperitonitis and Traumatic 
Pericarditis in Egyptian Cattle Turk. J. Vet. Anim. Sci. 34(2): 143-153.

Igbokwe, I. O., M. Y. Kolo., and G. O. Egwu (2003). Rumen Impaction in Sheep with Indigestible Foreign Body in The Semi Arid Region of Nigeria. Small Ruminant Res. 49(3): 141-147.

Kahn, J.M., G. Habib dan M.M Siddiqui, (1999) Prevalence of foreign indigestible materials in the reticulo-rumen of adult buffaloes. Pak. Vet. J. 19(4): 176-177.

Kumar, V., and Dhar, P (2013) Foreign Body Impaction in A Captive Sambar (Rusa unicolor), Vet world, 6(1): 49-50.

Nugusu, S., Velappagounder, R., Unakal, C., and Nagappan, R (2013) Studies on Foreign Body Ingestion and Their Related Complications in Ruminants Associated with Inappropriate Solid Waste Disposal in Gondar Town, North West Ethiopia. International Journal of Animal and Veterinary Advances 5(2): 67-74.

Oka, I. G. L., Suyadnya, I. P., Putra, S., Suarna, I. M., Suparta, I. N., Saka, I. K., Suwiti, Ni. K., Antara, I. M., Puja, I. N., Sukanata, I. W., Oka, A. A., and Mudita, I. M (2012) Sapi Bali Sumber Daya Genetik Asli Indonesia: Denpasar. Udayana University Press. ISSN: 978-602-9042-91-7. 1-16.
Omid, A. Mozaffari AA (2014) Reticulo-cutaneous fistula due to the ingestion of a long metallic rod in a cow. Asian Pac J Trop Biomed. 4 (7) : 586-588.

Roman, T., and Hiwot, Y (2010) Occurrence of Rumen Foreign Bodies in Sheep and Goats Slaughtered at The Addis Ababa Municipality Abattoir. Ethiopian. Vet. J., 14(1): 91-100.

Saulawa, M. A., Ukashatu, S., Garba, M. G., Magaji, A. A., Bello, M. B., and Magaji, A. S (2012) Prevalence of Indigestible Substances in The Rumen and Retikulum of Small Ruminants Slaughtered at Katsina Central Abattoir, Katsina State, Northwester Nigeria. Scientific Journal of Pure and Applied Sciences 1(1) 1721.

Suwandi (1997) Peranan Mikroba Rumen Pada Ternak Ruminansia. Bogor. Lokakarya Fungsional Non Penelitian. 13-19.

Tesfaye, D., and Chanie, M (2012) Study on Rumen and Retikulum Foreign Bodies in Cattle Slaughtered at Jimma Municipal Abattoir, South West Ethiopia. Am-Euras. J. Sci. Res., 7 (4): 160-167.

Vanitha, V., A. P Nambi., B. Gowri., and S, Kavitha (2010) Rumen Impaction in Cattle with Indigestible Foreign Bodies in Chennai. Tamil Nadu J. Vet.Anim. Sci.Univ., 6(3): 138-140. 